UNIVERSIDADE DE SÃO PAULO

ESCOLA DE ENGENHARIA DE LORENA

LISA GOMES ALVARELI

Avaliação de um tratamento enzimático para a produção de celulose

nanocristalina e recuperação dos açúcares solubilizados em alta concentração

Lorena, SP.

2017. 



\title{
Avaliação de um tratamento enzimático para a produção de celulose nanocristalina e recuperação dos açúcares solubilizados em alta concentração
}

\begin{abstract}
Dissertação apresentada à Escola de Engenharia de Lorena, da Universidade de São Paulo, para a obtenção do título de Mestre em Ciências do Programa de Pós-Graduação em Biotecnologia Industrial na área de concentração: Conversão de Biomassa.

Orientador: Prof. Dr. Valdeir Arantes
\end{abstract}

Versão Original.

Lorena, SP.

2017. 
AUTORIZO A REPRODUÇÃO E DIVULGAÇÃO TOTAL OU PARCIAL DESTE TRABALHO, POR QUALQUER MEIO CONVENCIONAL OU ELETRÔNICO, PARA FINS DE ESTUDO E PESQUISA, DESDE QUE CITADA A FONTE

Ficha catalográfica elaborada pelo Sistema Automatizado da Escola de Engenharia de Lorena, com os dados fornecidos pelo(a) autor(a)

Alvareli, Lisa Gomes

Avaliação de um tratamento enzimático para a produção de celulose nanocristalina e recuperação dos açúcares solubilizados em alta concentração / Lisa Gomes Alvareli; orientador Valdeir Arantes - Versão Original. - Lorena, 2017.

$102 \mathrm{p}$.

Dissertação (Mestrado em Ciências - Programa de Pós Graduação em Biotecnologia Industrial na Área de Conversão de Biomassa) - Escola de Engenharia de Lorena da Universidade de São Paulo. 2017

Orientador: Valdeir Arantes

1. Hidrólise enzimática. 2. Celulose

nanocristalina. 3. Adsorção enzimática. 4. Reciclagem enzimática. I. Título. II. Arantes, Valdeir, orient. 
Dedico este trabalho ao meu avô, João Baptista Gomes, "in memorian".

Saudades eternas, vovô. 



\section{AGRADECIMENTOS}

Agradeço a Deus por sempre estar comigo, me guiando nesta jornada que é a Vida e me ajudando a subir mais um degrau na vida acadêmica.

Ao meu orientador, Prof. Dr. Valdeir Arantes, pela oportunidade de fazer parte do grupo de pesquisa BBioPRO, pela excelente orientação ao longo do meu trabalho e por tudo que me ensinou nestes anos de convivência. Muito obrigada!

Aos meus pais, Sergio e Luciani, por sempre "segurarem a minha barra", sempre me colocando para cima e me fazendo acreditar que eu era e ainda sou capaz. Sem vocês eu não teria chegado até aqui.

Ao meu irmão e amigo, Sergio Jr., que mesmo morando longe sempre se fez presente. Você sempre foi uma grande inspiração para mim.

A toda minha família pelo apoio, carinho e união; obrigada por acreditarem em $\operatorname{mim}$.

À minha tia "E" madrinha, Sandra, por todo carinho, ajuda, dedicação e incentivo para entrar no programa; sem você eu não estaria hoje aqui escrevendo este agradecimento.

Aos meus colegas do grupo de pesquisa BBioPRO pela companheirismo, ajuda, debates, conversas, momentos de descontração e risadas. Muito obrigada.

Aos técnicos, funcionários e amigos dos laboratórios dos diversos departamentos da EEL-USP pela amizade, respeito e ajuda de sempre.

Agradeço à Coordenação de Aperfeiçoamento de Pessoal de Nível Superior (CAPES) pela concessão da bolsa durante o período de realização deste trabalho de mestrado.

À EEL-USP, pela oportunidade de estudar, realizar e concluir mais uma etapa da minha vida. 



\section{RESUMO}

ALVARELI, L. G. Avaliação de um tratamento enzimático para a produção de celulose nanocristalina e recuperação dos açúcares solubilizados em alta concentração. 2017. 102p. Dissertação (Mestrado em Ciências) - Escola de Engenharia de Lorena, Universidade de São Paulo, Lorena, 2017.

As celuloses nanocristalinas (CNC) são partículas de, pelo menos, uma dimensão nanométrica, possuem baixa densidade, alta resistência e área de superfície para realizar modificações químicas, podendo melhorar as propriedades de materiais compósitos. O método mais tradicional para isolar CNC é por hidrólise ácida com ácido sulfúrico, porém este procedimento apresenta desvantagens. Além disso, a ação não seletiva do ácido também ataca as regiões cristalinas levando a um baixo rendimento de produção, e a obtenção de uma suspensão muito diluída de açúcares solubilizados e outros compostos indesejáveis, o que inviabiliza a recuperação dos açúcares. Outra possibilidade para 0 isolamento de $\mathrm{CNC}$ envolve a utilização de preparos enzimáticos de celulases, uma alternativa promissora. Porém, a utilização de baixa carga de polpa celulósica e alta quantidade de enzima tipicamente utilizadas na rota enzimática para obter nanocristais são fatores limitantes. A fim de tentar superar estes problemas, este trabalho teve como objetivo avaliar um sistema de tratamento enzimático em duas etapas para possibilitar a condução do tratamento enzimático em alta concentração de polpa celulósica e baixa dose de enzimas e permitir a produção de CNC e recuperar os açúcares solubilizados em alta concentração. Os resultados mostraram que ao realizar uma hidrólise com baixa carga de sólidos e com suplementação de $\beta$ glicosidade foi possível obter uma conversão de celulose 30\% maior, mas uma significativa redução da eficiência enzimática foi observada quando a carga de sólidos foi aumentada, mesmo utilizando a suplementação.Por meio do sistema de duas etapas, foi possível obter uma conversão de celulose e uma concentração de açúcares relativamente alta, além de obter CNC com propriedades comparáveis as obtidas em situações tradicionais de hidrólises. No entanto, o diferencial da hidrólise aplicando o sistema de duas etapas se caracterizou pela utilização de, aproximadamente, metade da quantidade de enzimas utilizadas nas hidrólise tradicionais. Alem disso, o sistema em duas etapas possibilitou a reciclagem das enzimas não adsorvidas para reações de hidrólises subsequentes, se mostrando mais um fator de destaque para a área de conversão enzimática. Conclui-se, portanto, que este sistema se mostrou muito eficiente e promissor o que é interessante do ponto e vista econômico para processos subsequentes à hidrólise.

Palavras-chave: Hidrólise enzimática. Celulose nanocristalina. Adsorção enzimática. Reciclagem enzimática. 


\section{ABSTRACT}

ALVARELI, L. G. Evaluation of an enzymatic treatment for the productionofnanocrystallinecelluloseandrecoveryofsolubilizedsugars in high concentration. 2017. 102p. Dissertation (Master of Science) - Escola de Engenharia de Lorena, Universidade de São Paulo, Lorena, 2017.

Nanocrystalline celluloses (CNC) are particles of at least one nanometric dimension, have low density, high strength and surface area to perform chemical modifications, and can improve the properties of composite materials. The most traditional method for isolating $\mathrm{CNC}$ is by hydrolysis with sulfuric acid, however this procedure has drawbacks. In addition, the non-selective action of the acid also attacks the crystalline regions leading to a low yield of production, and obtaining a very diluted suspension of solubilized sugars and other undesirable compounds, which impairs prevents the recovery of sugars. Another possibility for the isolation of CNC involves the use of enzymatic preparations of cellulases, a promising alternative. However, the use of low cellulosic pulp load and high amount of enzyme typically used in the enzymatic route to obtain nanocrystals are limiting factors. In order to overcome these problems, this work had as objective to evaluate a system of enzymatic treatment in two stages to enable the conduction of the enzymatic treatment in high concentration of cellulose pulp and low dose of enzymes and to allow the production of CNC and to recover the solubilized sugars in high concentration. The results showed that when hydrolysis was carried out with low solids loading and with $\beta$-glycoside supplementation, 30\% higher cellulose conversion was achieved, but a significant reduction of the enzymatic efficiency was observed when solids loading was increased, even using by means of the two-stage system, it was possible to obtain relatively high cellulose conversion and sugar concentration, in addition to obtaining CNCs with properties comparable to those obtained in traditional hydrolysis situations. However, the differential of the hydrolysis applying the two-stage system was characterized by the use of approximately half the amount of enzymes used in traditional hydrolysis. In addition, the two-step system allowed the recycling of the non-adsorbed enzymes to subsequent hydrolysis reactions, showing another important factor for the enzymatic conversion area. It is concluded, therefore, that this system proved very efficient and promising what is interesting from the economic point of view of processes subsequent to the hydrolysis.

Keywords: Enzymatic hydrolysis. Cellulose nanocrystals. Enzymatic adsorption. Enzymatic recycling. 